\title{
Van der Walt, B J - Kultuur, lewensvisie en ontwikkeling
}

Potchefstroom: Potchefstroomse Instituut vir Reformatoriese Studies, PU vir CHO. Prys: Onvermeld

\section{Resensent: Ernst Wolf}

Die probleem waarop Van der Walt in hierdie boek reageer, is dat ontwikkeling, wat in ons tyd so 'n prominensie geniet, ongewensde gevolge het. As mens ten spyte van die talle mislukte ontwikkelingspogings tog nie van ontwikkeling as sodanig wil afsien nie, is die vraag dan hoe dit nuut bedink kan word. Tot hierdie debat oor die uitgangspunte vir ontwikkeling veral in Afrika wil Van der Walt 'n bydrae maak.

Sy vertrekpunt is dat die oplossing tot die probleme wat tans met ontwikkeling beleef word, nie bloot op ekonomies-tegniese vlak aangespreek kan word nie, omdat hierdie praktiese vlak van lewensbeskoulike, kulturele en godsdienstige onderbou afhanklik is. 'n Diepgrondige heroorweging van ontwikkeling moet dus eerstens by hierdie onderbou stilstaan. So 'n ondersoek wys uit dat daar twee groot kulture is wat die kern van konsepsies van ontwikkeling vorm, naamlik dié van die Weste en dié van Afrika. 
Beide benaderings moet krities getvalueer word. Maar as ons hierdie kulturele kern van ontwikkeling nie net wil verstaan nie, maar wil evalueer, word ons met 'n probleem gekonfronteer: hoe kan mense wat onderskeidelik vanuit 'n Westerse of 'n Afrika-kultuur leef, mekaar se verskillende benaderings tot ontwikkeling beoordeel? Die manier waarop Van der Walt hierdie probleem hanteer, is om 'n derde lewensbeskoulike- of godsdienstige standpunt voor te stel van waaruit die ander twee beoordeel kan word en van waaruit norme gevind kan word aan die hand waarvan ontwikkeling voortaan gedoen behoort te word. Hierdie derde standpunt is die Bybels-Reformatoriese, Christelike godsdiens. Vanuit hierdie perspektief formuleer Van der Walt 'n definisie van ontwikkeling wat opsommend die sleutel tot sy boek is: "Ontwikkeling is die gebalanseende ontsluiting van al die vermokns van die mens en die moontlikhede van die res van die skepping volgens God se doel daarmee en wil daarvoor, sodat die mens in staat is om in sy eie kultuur sy roeping as verantwoordelike rentmeester in vryheid in die samelewing tot eer van God te vervul." ( $p$ 46)

Om te sien hoe die skrywer dit doen, gee ek 'n voelvlug oor die inhoud van die boek.

Die boek word omraam met 'n inleiding, waarin die basiese vertrekpunte uiteengesit word, en 'n terugblik (hoofstuk 7) waarin die inhoud kortliks opgesom word.

Hoofstuk 1 motiveer die belang van 'n kulturele invalshoek, wat die lewensbeskoulike agtergronde (tyds-, samelewings-, mens-, natuur-, wets- en godsbeskouing) wat agter elke ontwikkelingskonsepsie sit. Voorts word daar aan die hand van Van der Walt se verstaan van die Skrif se beeld van die verloop van wereldgeskiedenis, naamlik skepping - sondeval - herskepping (p. 20), 'n normatiewe grondslag van die derde (Christelike) perspektief op ontwikkeling uiteengesit.

In hoofstuk 2 word die groeiende aandag aan kultuur in ontwikkelingsdenke beskryf en die verhouding tussen die twee sake word verstaan as "ontwikkeling as kultuur" eerder as "ontwikkeling en kultuur". Voorts word verskillende aspekte van kultuur (met die klem op lewensvisie) uiteengesit sodat ontwikkeling as kultuur aan die hand daarvan geïnterpreteer kan word. Die begrip van ontwikkeling word ook aan die hand van hierdie verstaan van kultuur verbreed en die norme van 'n gesonde lewensvisie word uiteengesit. Ontwikkelingswaardes vanuit 'n Islamitiese perspektief word vinnig bekyk.

Die hoofdoel van hoofstukke 3 en 4 is om die kultureel-godsdienstige agtergronde waarvit ontwikkeling in onderskeidelik Afrika en die Weste verstaan of aangepak word, aan die hand van die reeds neergelegde norme te beoordeel. Die klem lê daarop om in albei gevalle die perke uit te wys en voorstelle aan die hand te doen oor die rigting waarin die herstel van hierdie twee lewensvisies gesoek kan word.

in hoofstuk 5 probeer Van der Walt om die ideologiese veronderstellings in die ontwikkelingswerk van (hoofsaaklik) die Wereldbank bloot te le en te kritiseer. Die noodsaak om Christelik profeties hierteen te reageer word benadruk.

Hoofstuk 6 wil aantoon dat die oorsaak vir die ontwikkelingsprobleme gelek is in 'n gebrekkige besef van die noodsaak om ontwikkeling vanuit Christelike norme te beoefen. Literatuur word voorgestel waarin Reformatoriese alternatiewe op kontemportre ontwikkelingsidees gesoek kan word.

Ten slotte wil ek 'n paar kritiese opmerkings maak. Die boek kan waardeer word vir die vasberadenheid wat Van der Walt daarin toon om sy geloofsoortuigings in die konteks van hiendie kontensieuse tema op relevante wyse te laat vorm kry. Maar dit is juis die aand van hierdie teologiese uitgangspunt wat ook vir Christene problematies kan wees. Van der Walt toon min histories/sosiaal-kritiese begrip in sake sy teologiese standpunt nie. Dit geld vir sowel vir sy gebruik van die Bybel as vir die Gereformeende tradisie waarin hy staan. Dit beteken dat hy aspekte van die Bybel wat vir ander mense (ook gelowiges) na toevallige kultuureiendomlikhede van die ou mense mag lyk, tot God-geopenbaarde norme verhef. 'n Voorbeeld hiervan is die Bybel se tydsbeskouing, maar ook Van der Walt se rekonstruksie van die Skrif se beeld van wereldgeskiedenis (p. 20) 'n Vreemde uitvloeisel hiervan is dat daar regdeur die boek verwys 
word na die kultuur van Afrika as "voor-Christelik" (en nie bv voor-Boeddhisties nie) - iets wat net moontlik is om te sê as mens spesiale insae in die toekoms het. Nog 'n voorbeeld waar die kultuur van die outeur se teologie verklap word, is in sy bespreking van duiwels en bose magte (p 108-9). Die besondere waarheidskonsepsie van die Gereformeerde Christendom word onkrities oorgeneem in 'n konteks waar dit van die uiterste belang is om dit raak te sien. Vir sommige lesers mag dit ook as vreemd opval dat Van der Walt vanuit die Bybel in teologiese debat gaan met tipiese aspekte van Afrika-godsdienste, so asof daar enigsins ' $n$ gemeenskaplike gesaghebbende verwysingspunt is. Van der Walt aanvaar dat Christelike etiek noodwendig deontologies is en dat die Christelike norme vir mense van alle godsdienste sou geld (as dit vir alle mense geld, geld die eerste norm, naamlik dat mense die God van die Christelike geloof moet dien, ook vir almal). Dit sal beteken dat ontwikkeling net suksesvol gedoen kan word as alle mense hulle tot die Christelike geloof sou bekeer. Een van die veronderstellings in die boek is dat as mens maar net die aangetoonde norme gehoorsaam, dan sal alles in ontwikkeling reg verloop (geskiedenis loop immers van sondeval na herskepping!). Behalwe vir 'n vinnige verwysing ( $p$ 191) toon die outeur geen sensitiwiteit vir die probleem van die lydende regverdige nie (soos in die protes-Wysheid) of vir die tema van geloof ten spyte van lyding nie (soos in groot dele van die Nuwe Testament). 